\title{
TENSIONAMENTOS SOCIAIS E JUSTIÇA DE TRANSIÇÃO: CONTRIBUIÇÕES AO CONSTITUCIONALISMO LATINO-AMERICANO
}

SOCIAL TENSIONS AND TRANSITIONAL JUSTICE: CONTRIBUTIONS TO LATIN AMERICAN CONSTITUTIONALISM

TENSIONAMIENTOS SOCIALES Y JUSTICIA DE TRANSICIÓN: CONTRIBUCIONES AL CONSTITUCIONALISMO LATINOAMERICANO

\section{Roberta Camineiro Baggio}

Resumo: Partindo da ideia de que os tensionamentos sociais podem estabelecer importantes zonas de tensões institucionais capazes de despertar e aprofundar práticas legitimadas pelos textos constitucionais, o presente artigo objetiva caracterizar a justiça de transição como um campo de tensionamento que tem se revelado extremamente importante para o aperfeiçoamento das democracias latino-americanas.

Palavras-chave: Tensionamentos Sociais. Justiça de Transição. Constitucionalismo Latino-Americano.

1 Professora adjunta da Faculdade de Direito da Universidade Federal do Rio Grande do Sul, doutora em Direito pela Universidade Federal de Santa Catarina e conselheira da Comissão de Anistia do Ministério da Justiça. E-mail: robertabaggio@uol.com.br. 
Abstract: Starting from the idea that social tensions may provide important areas of institutional tensions able to awaken and deepen practices legitimized by constitutional texts, this study aims to characterize transitional justice as a field of tension that has turned out to be extremely important for the improvement of Latin American democracies.

Keywords: Social Tensions. Transitional Justice. Latin American Constitutionalism.

Resumen: Partiendo de la idea de que los tensionamientos sociales pueden establecer importantes zonas de tensiones institucionales capaces de despertar y profundizar prácticas legitimadas por los textos constitucionales, el presente artículo se propone caracterizar la justicia de transición como un campo de tensionamiento que se ha revelado extremadamente importante para el perfeccionamiento de las democracias latinoamericanas.

Palabras clave: Tensionamientos Sociales. Justicia de Transición. Constitucionalismo Latinoamericano.

\section{INTRODUÇÃO}

\footnotetext{
ntre as décadas de 1960 e 1990 diversos países da América Latina vivenciaram experiências de regimes políticos de exceção, seja pela via dos golpes de Estado, seja pelos conflitos internos armados.
}

As transições desses regimes foram marcadas, sob o ponto de vista jurídico, por processos de reconstitucionalização que englobam tanto a restauração dos textos constitucionais anteriores - incluindo as reformas sofridas a posteriori -, como a instituição de novas constituições por meio de Assembleias Constituintes.

O simples advento da implementação de novos textos constitucionais ou a tentativa de retomada da legitimidade daqueles que foram ignorados pelos 
regimes de exceção, no entanto, não constituem causas imediatas de garantias de direitos ou medidas automáticas de uma ampla produção de efeitos normativos, sobretudo, na retomada das bases do Estado Constitucional de Direito. E, nesses contextos, o modus operandi das transições políticas é decisivo para a consolidação de condições políticas e jurídicas que favoreçam a efetivação dos textos constitucionais. Tais condições passam necessariamente pela construção social de estratégias de tensionamento que se imponham aos diversos âmbitos institucionais em reformulação.

A forma como, por exemplo, a Argentina conduziu seu processo de transição política tanto por meio dos grupos sociais vinculados ao debate da defesa dos direitos humanos mobilizados em torno das questões transicionais como institucionalmente, com ênfase na busca pela memória e verdade sobre as violações aos direitos humanos ocorridas durante o período do Estado de exceção e a posterior construção de possibilidades jurídicas de responsabilização dos agentes estatais, impulsionou internamente um debate amplo sobre a necessidade de proteção dos direitos humanos, que permitiu um avanço no campo da aplicabilidade interna do direito internacional dos direitos humanos com a adoção pelo texto constitucional, na reforma de 1994, do inciso 22 do art. 75, que reconheceu a hierarquia constitucional de tratados e convenções internacionais no plano interno. Esse processo não ocorreu sem resistências ou grandes tensionamentos internos tanto por parte da sociedade civil como em âmbito institucional e, é justamente a existência dessas tensões, que permite ou até mesmo impõe a necessidade de que o debate público acerca das demandas político-constitucionais seja enfrentado no campo das disputas valorativas da sociedade ${ }^{2}$ e, também, nas instituições constituídas como parte do poder estatal.

2 A concepção político-filosófica que permeia o presente artigo é a teoria do reconhecimento de Axel Honneth, herdada da tradição filosófica hegeliana que, ao estabelecer três níveis de reconhecimento indispensáveis para a formação de uma dinâmica de integração da sociedade, identifica um deles como o da comunidade de valores. Esse seria o nível em que os diversos desacordos morais se consolidam e as disputas valorativas determinam um campo de eticidade. Os conflitos sociais geradores de tensionamentos no campo político-institucional seriam fruto dessas disputas. Para uma leitura sobre uma concepção de justiça de transição como reconhecimento conferir: BAGGIO, Roberta Camineiro. Justiça de transição como reconhecimento: limites e possibilidades do processo brasileiro. In: Repressão e memória política no contexto ibero brasileiro: estudos sobre Brasil, Guatemala, Moçambique, Peru e Portugal, Brasília, DF: Ministério da Justiça. Comissão de Anistia, 2010. p. 260-285. 
Em sociedades democráticas, a existência de tensionamentos políticos que possibilitem a constante reflexão sobre a prática constitucional e o aumento de processos de integração social é essencial, nas sociedades em transição política eles são imprescindíveis se o que está em jogo é a efetivação de direitos.

O que se pretende debater no presente texto são as possíveis potencialidades trazidas pelos pilares da chamada Justiça de Transição para a sustentação de campos de tensionamento político-institucional que podem significar avanços no sentido da consolidação da força normativa dos textos constitucionais latinoamericanos e, também, do aprofundamento da dinâmica entre direito e política e seus reflexos no campo da proteção aos direitos humanos. Ao final, será dada uma ênfase ao caso brasileiro, especificamente no que tange aos tensionamentos da temática transicional que permeiam o Supremo Tribunal Federal a partir da análise das extradições 974, 1150 e 1278.

\section{OS PROCESSOS DE RECONSTITUCIONALIZAÇÃO LATINO- AMERICANOS E A NOTÓRIA QUESTÃO DA EFETIVIDADE DOS TEXTOS CONSTITUCIONAIS}

O debate acerca da produção de efeitos dos textos constitucionais tem um lugar central no âmbito da teoria da constituição, potencializado, sobretudo, pela clássica leitura de Ferdinand Lassale, enfrentada com a devida adaptação temporal por autores de contribuição inestimável ao constitucionalismo contemporâneo como Konrad Hesse em A força normativa da Constituição. Nesses termos, um olhar sociológico mais rígido não resiste ao reducionismo da concepção das Constituições como meras folhas de papel sob a perspectiva de que só entrariam de fato no mundo real as disposições constitucionais que as forças políticas predominantes permitissem. Na visão de Lassale, em oposição à folha de papel, há uma Constituição real, gerada pelo embate de fatores reais de poder ${ }^{3}$. Nessa leitura lassaliana há a importante percepção sobre os fatores reais de poder como grupos que disputam na sociedade as diversas visões políticas geradoras de tensionamentos capazes de determinar uma Constituição real, não 3 LASSALE, Ferdinand. A Essência da Constituição. Rio de Janeiro: Lumen Juris, 2000. 
coincidente com a Constituição escrita. As Constituições seriam, sob esse ponto de vista, políticas e não jurídicas.

Os textos constitucionais, todavia, estabelecem pactos jurídico-políticos geradores de expectativas normativas próprias de um Estado de Direito. Afinal, como destaca Hesse, "Embora a Constituição não possa, por si só, realizar nada, ela pode impor tarefas" ${ }^{\prime \prime}$. Partindo do pressuposto de que os textos constitucionais, inseridos em conjunturas históricas específicas, contemplam metas normativas de superação de problemas reais das sociedades, essa imposição de tarefas requer uma série de medidas institucionais que passam a ser necessárias para sua efetivação.

Contudo, as diferentes compreensões políticas sobre os problemas sociais, e até mesmo as concepções acerca das instituições, geram uma série de disputas, muito bem identificadas por Lassale, em torno das questões jurídico-políticas pautadas pelas constituições e, desse embate específico, diferentemente do que conclui o autor, contudo, pode se estabelecer uma dinâmica de efetivação normativa do texto constitucional. Isto porque, longe de significar uma construção harmoniosa com garantia de efetivação plena de seus textos, as Constituições pertencem, como coloca Marcelo Neves, a contextos paradoxais em que o que predomina é uma tensão constante entre as esferas da política e do direito ${ }^{5}$, que acaba por gerar a força motora para que os grupos sociais se organizem em torno das disputas valorativas que incidirão no estabelecimento dos sentidos constitucionais.

No contexto latino-americano, essa questão constitui-se como chave de compreensão dos processos constitucionais das transições políticas. A restauração das cartas constitucionais anteriores aos períodos de exceção ou a instituição de novas constituições representa, ao menos sob o ponto de vista formal, o retorno aos parâmetros próprios de um Estado de Direito, que se pretende democrático em oposição ao período anterior, o que inclui o restabelecimento público dos tensionamentos sociais outrora impedidos pelos regimes de exceção. E é exatamente nesse contexto de possibilidade do ressurgimento de tensões constantes que essas cartas constitucionais precisam ser compreendidas. As Constituições latino-americanas desse período são conhecidas por seu extenso 4 HESSE, Konrad. A força Normativa da Constituição. Porto Alegre: Sérgio Fabris, 1991. p. 19. 5 NEVES, Marcelo. Transconstitucionalismo. São Paulo: Martins Fontes, 2009. p. 57. 
rol de direitos fundamentais - que abarca não só aqueles tradicionais que foram negados durante os períodos de exceção como também novos direitos fundamentais, como as questões vinculadas à proteção do meio ambiente e ao reconhecimento da cultura indígena, o que gerou e ainda gera uma série de críticas acerca das dificuldades de efetivação normativa de seus textos. ${ }^{6}$

Um exemplo dessa crítica pode ser encontrado em Giovanni Sartori, na obra Engenharia Constitucional. Segundo o autor, usand o o caso brasileiro, a Constituição de 1988 seria uma "novela do tamanho de um catálogo telefônico" e "repleta não só de detalhes triviais como de dispositivos quase suicidas e promessas impossíveis de cumprir"7. Ainda que o autor tenha razão em afirmar que "as Constituições não devem conter o que compete à legislação ordinária" ${ }^{8}$, as Constituições latinoamericanas dos períodos posteriores aos Estados de exceção carregam em si o peso político da retomada de uma condição mínima de segurança jurídica aos cidadãos, inerente aos Estados de Direito, sobretudo, no que diz respeito à garantia de direitos fundamentais básicos como os políticos e as liberdades individuais.

Especificamente, no caso brasileiro, a Constituição de 1988, fruto de uma Assembleia Constituinte instaurada em pleno processo de reabertura política do país, simbolizou a grande chance jurídico-formal de restabelecer ao país um regime democrático. Natural, portanto, que diante da tamanha instabilidade vivida em um processo transicional conduzido pelos próprios militares responsáveis pela manutenção do regime de exceção, tenha existido uma tendência em colocar o máximo de prerrogativas e garantias jurídicas no texto constitucional, ainda que sua produção de efeitos fosse uma incógnita para a época, afinal, não se havia conseguido, sequer, garantir eleições diretas para a Presidência da República, apesar da ampla mobilização nacional, em 1984, pelo movimento que ficou conhecido como "Diretas Já". Há autores como Raymundo Faoro que denunciaram a falácia da constituinte de 1986, pois não seria uma assembleia exclusiva a responsabilizar-se pelo novo texto constitucional, mas sim o poder constituído, 6 GARGARELA, Roberto; COURTIS, Christian. El nuevo constitucionalismo latinoamericano: promesas e interrogantes. CEPAL, Serie Políticas Sociales, Santiago de Chile, n. 153. nov. 2009. p. 31.

7 SARTORI, Giovanni. Engenharia Constitucional: como mudam as constituições. Brasília: UnB, 1999. p. 211.

8 SARTORI, Giovanni. Engenharia Constitucional: como mudam as constituições. p. 211. 
uma vez que o Congresso se transmutaria em constituinte para aprovar a nova Constituição. Considerando que o poder instituído ainda estava nas mãos de quem comandava o regime ditatorial, compreensíveis as denúncias de Faoro e a sua descrença em um resultado constitucional que pudesse significar um avanço democrático ao país. Isso fica claro na seguinte passagem em que, segundo o autor, no movimento pelas Diretas Já,

O povo saiu de casa, se reuniu, clamou pela soberania de sua vontade - o que é a Constituinte, no seu sentido autêntico, real, genuíno, sem máscaras. Esta a Constituinte que ele quer, não a Constituinte que os políticos tentam Ihe vender, embutida dentro do Congresso Nacional, manobrada de cima, do alto, meramente para reescrever a Constituição atual, sobre um projeto das espertas elites. ${ }^{9}$

O resultado não foi exatamente esse. Apesar de todos os paradoxos que rondavam a elaboração da nova Constituição, incluindo nesse contexto as próprias escolhas ideológicas duvidosas dos constituintes-deputados, a Constituição de 1988, sem estar livre de contradições, consolidou-se como a melhor das Constituições da história brasileira, sobretudo, pelo reconhecimento de um importante rol de garantias e direitos fundamentais que inspirou seu batismo como Constituição Cidadã. Com o passar dos anos e a consolidação de um regime democrático formal, a Constituição afirmou-se como o marco zero para o processo de redemocratização da sociedade brasileira, contudo, no momento de sua elaboração, não era e nem poderia ser esse o sentimento que predominava na sociedade. É como se, considerando a classificação das constituições de Karl Loewenstein, a Constituição brasileira de 1988 fosse uma constituição nominal, cujo momento de elaboração impedia sua completa integração à dinâmica da vida política, mas as expectativas ao seu redor giravam em torno da ideia de que cedo ou tarde poderia consolidar-se como uma constituição normativa ${ }^{10}$.

Portanto, uma compreensão superficial sobre os contextos que permeiam esses momentos transicionais, presentes nos processos de reconstitucionalização latinoamericanos, não contribui para uma análise mais ampla acerca das consequências

9 FAORO, Raymundo. Constituinte ou Congresso com Poderes Constituintes? In: Constituição e Constituinte. São Paulo: RT, 1987. p. 11-28. p. 15.

10 LOEWENSTEIN, Karl. Teoría de la constitución. Barcelona: Ariel, 1979. p. 218. 
e dos significados políticos de textos constitucionais que incorporam garantias de direitos há muito impraticáveis nessas sociedades, afinal, a existência de uma Constituição, ainda que cumpra um papel incipiente de simbolizar a retomada formal da democracia, pode ser decisiva para impulsionar novas formas de tensionamentos públicos que garantam, na dinâmica social, a consolidação substancial de processos democráticos.

Depois de longos períodos de violações aos direitos sem qualquer prática de efetividade das Constituições, principalmente no tocante às garantias e aos direitos fundamentais, a retomada desses textos normativos não só não ocorre automaticamente, como depende de fatores conjunturais intimamente ligados às decisões políticas que conduzem os processos transicionais, bem como à capacidade de tensionamento dos grupos sociais que buscam participar ou influenciar de algum modo tais decisões.

A partir de uma leitura assentada na realidade latino-americana, Roberto Gargarella e Christian Courtis avaliam que os dispositivos constitucionais podem ficar adormecidos por muitos anos, sem que isso revele por si só a representação de enfraquecimento normativo de uma Constituição. Ao contrário, segundo os autores:

[...] una cláusula relegada o 'adormecida' puede cobrar inesperada realidad, puede despertar de su letargo - un hecho que de ningún modo puede verse como una anomalía en el derecho, ya que es puro y directo producto de la incorporación explícita de ciertas cláusulas en un texto que se asume como plataforma social compartida. ${ }^{11}$

Catálogos telefônicos ou não, os textos constitucionais consolidados após os regimes de exceção representam um ponto de partida político e jurídico para essas sociedades e, como tal, oportunizam a geração de tensionamentos a partir de sua existência pura e simples, assim como podem instrumentalizar disputas políticas que acabem reforçando sua força normativa. Em qualquer desses cenários, a existência de direitos e dispositivos de melhoria das condições relacionais da vida em sociedade nos textos constitucionais indica a potencialidade normativa

11 GARGARELA, Roberto; COURTIS, Christian. El nuevo constitucionalismo latinoamericano: promesas e interrogantes. p. 33. 
de questões que estão abertas a transformar-se em novos focos de disputas político-sociais e processos capazes de "despertar" os textos constitucionais. E é nesse sentido que a existência de campos de tensão sociais que alcancem o âmbito institucional deve ser compreendida como imprescindível para o avanço dos processos de redemocratização latino-americanos.

Em tradições de baixa efetivação constitucional, como é o caso dos países latino-americanos, a ausência de prescrição normativa desses direitos, sobretudo dos novos, pode levar a uma dificuldade por parte do poder judiciário em aceitar sua legitimidade, já que, de acordo com Gargarella e Courtis, "[...] parece haber una alta correlación entre la no inclusión de nuevos derechos y el no reconocimiento judicial de los nuevos derechos"12, sobretudo em países com uma tradição positivista herdada do direito continental europeu, que exige como fonte primária do direito normas positivadas. Sob esse ponto de vista estrito, a presença desse extenso rol de direitos é não só compreensível no sentido da adequação constitucional às realidades históricas de países que passaram por sérios problemas de violações aos direitos, como também relevante no tocante ao empoderamento dos cidadãos, na medida em que esses direitos podem tornar-se motores substantivos da retomada da sua condição política na sociedade. Por isso, ao responder a crítica do extenso rol de direitos nos textos constitucionais latino-americanos, Gargarella e Courtis chamam a atenção, em um primeiro momento, para o fato de que em países como Colômbia e Argentina "[...] estos textos tan exigentes y llenos de derechos no se han convertido en 'pura poesía'"13 e depois, avaliam que:

[...] gracias al status constitucional que se le ha asignado a algunos reclamos, se han reivindicado los derechos de muchas personas de carne y hueso. Por ejemplo, grupos de indígenas y homosexuales, habitualmente maltratados en sus derechos fundamentales, han encontrado respaldo en estas Constituciones y litigado - en algunos casos importantes, al menos - de modo exitoso, frente a los tribunales. $\mathrm{Y}$ ello, en buena medida, gracias a lo escrito en estas nuevas

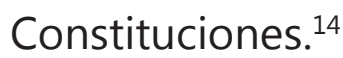

12 GARGARELA, Roberto; COURTIS, Christian. El nuevo constitucionalismo latinoamericano: promesas e interrogantes. p. 32.

13 GARGARELA, Roberto; COURTIS, Christian. El nuevo constitucionalismo latinoamericano: promesas e interrogantes. p. 32.

14 GARGARELA, Roberto; COURTIS, Christian. El nuevo constitucionalismo latinoamericano: promesas e interrogantes. p. 32. 
Conforme destacam os autores, não se quer com isso negar que esses textos constitucionais sofrem de uma inflação de direitos, mas que rechaçar completamente as consequências positivas desses marcos constitucionais, principalmente no tocante à garantia de direitos desprezados até então, e não considerar as potencialidades políticas trazidas pelos tensionamentos inerentes à temática da retomada do processo democrático, marcado pelo rol de garantias constitucionais, pode constituir-se como um prejuízo para a compreensão da retomada dos processos de redemocratização.

Contudo, é necessário resgatar a noção trazida por Marcelo Neves, citada anteriormente, quanto à necessidade de considerar os paradoxos como questões inerentes aos contextos aos quais estão ligadas às Constituições. Se, por um lado, o extenso rol de direitos trazidos pelos textos constitucionais possibilitou o exercício efetivo de direitos por pessoas de carne e osso, por outro lado, o grande tensionamento que se consolidou como ferramenta para esse efetivo exercício foi o fenômeno da judicialização, que desnuda consequências gravosas para o campo da relação entre direito e política, podendo abalar consideravelmente o espaço de alargamento democrático das sociedades latino-americanas.

Ainda que a judicialização seja um fenômeno vinculado, em linhas gerais, às transformações do Estado Social e sua posterior crise e, portanto, existente em diversas sociedades contemporâneas, é importante sublinhar as peculiaridades conjunturais latino-americanas que permitiram não só seu rápido desenvolvimento como também o agravamento de muitas de suas consequências.

Não há uma definição teórica sobre as origens, as características e as consequências do fenômeno da judicialização, o que dificulta o estabelecimento de parâmetros mais uniformes para as análises que englobam o tema ${ }^{15}$. De todo modo, em linhas bem amplas, é possível afirmar que as leituras mais recorrentes desse fenômeno identificam que, diante da ausência de ação estatal na formulação de políticas públicas capazes de efetivar os direitos sociais, o Poder Judiciário sobretudo na América Latina - passou a uma postura mais ativista, tornando-se

15 VERONESE, Alexandre. A judicialização da política na América Latina: panorama do debate teórico contemporâneo. In: Escritos. Revista da Fundação Casa de Rui Barbosa, Rio de Janeiro, ano 3, n. 3, p. 249-281. jan. 2009. 
protagonista desse processo de efetivação. Esse cenário poderia indicar uma disputa entre os poderes executivo, legislativo e judiciário ou, ainda, a falência ou a diminuição do espaço da política que passa a ser ocupada cada vez mais pelo Poder Judiciário ${ }^{16}$.

Contudo, se, por um lado, para alguns autores o fenômeno da judicialização tem o mérito de impor um novo ritmo ao processo de dar concretude a alguns direitos estabelecidos nos textos constitucionais, por outro ele gera um problema sério no âmbito político, uma vez que o Poder Judiciário passa a interferir no campo das decisões políticas ${ }^{17}$. A simples existência de um rol mais extensivo de direitos por si só, de acordo com Gargarella, pode significar uma ameaça ao espaço de discussões democráticas. Primeiro, porque diminui o poder de decidibilidade das maiorias sobre determinados assuntos da vida política, depois porque a inclusão de mais direitos nos textos constitucionais corresponde imediatamente a um fortalecimento dos órgãos judiciais, que se sobressaem como os principais responsáveis pela custódia desses direitos, mas que, contudo, estão mais distantes de processos de legitimação política. ${ }^{18}$

Se esses seriam problemas a priori colocados pela existência pura e simples de um extenso rol de direitos, é preciso considerar como consequências principais do fenômeno da judicialização para a seara da relação entre direito e política que: (1) nos países latino-americanos em que as sociedades estão constituídas

16 Júlio Aurélio Vianna Lopes afirma que "O direito não é mais instituído para ou pela política; passa a ser instituinte dela, na medida em que legislar e administrar vão se tornando meros modos de regulamentação de princípios jurídicos superiores (legais, constitucionais, supraconstitucionais) ao Estado. O direito não é mais a argamassa das obras políticas; é o ácido que as corrói, desmanchando-as e substituindo-as por suas próprias instituições. LOPES, Júlio Aurélio Vianna. A invasão do direito. Rio de Janeiro: FGV, 2005. P. 65-6.

17 Veronese chama a atenção como um possível risco do debate latino-americano sobre a judicialização a restrição do tema a essas duas posições: "(a) a judicialização é benéfica, desde que amplie os cânones liberais do direito (Javier Couso); ou, ela é benfazeja, desde que mantida sob o controle popular (Yepes, Sousa Santos, etc.); ou (b) a judicialização é negativa porque expropria o espaço real da política, diminuindo a possibilidade de autogoverno e a democracia (Ran Hirschl)". Como o objeto desse trabalho não consiste na tentativa de superação desse risco, adotam-se essas duas posições exatamente por serem as mais recorrentes na literatura latino-americana. VERONESE, Alexandre. A judicialização da política na América Latina: panorama do debate teórico contemporâneo. In: Escritos. Revista da Fundação Casa de Rui Barbosa, Rio de Janeiro, ano 3, n. 3, p. 249-281. jan. 2009. p. 277.

18 GARGARELA, Roberto. Apuntes sobre el constitucionalismo latinoamericano del siglo XXI. Apuntes históricos. Revista del Instituto de Ciencias Jurídicas de Puebla, México, p. 30-48. 2010. p. 38. 
em fortes bases de desigualdades econômico-sociais, a judicialização privilegia somente algumas parcelas da população que conseguem acessar o Poder Judiciário; (2) os resultados desses processos judicializados, ainda que tratem da efetivação dos direitos sociais, acabam em sua maior parte alcançando um contingente humano muito menor do que se comparados aos resultados possíveis por meio da implementação de políticas públicas; (3) por fim, há um esvaziamento da esfera de lutas políticas por parte da sociedade, uma vez que a aderência à via judicial geraria uma conformidade isolada e não politizada. Enzo Bello sintetiza muito bem essas limitações trazidas pela prática da judicialização na seguinte análise:

Isso demonstra um desprezo das dimensões política e social, e a aposta somente nas dimensões ética e jurídica dos direitos sociais para a sua efetivação. Em razão disso, deixa-se de perceber que se está diante de casos extremos e contingentes, de grande relevância, porém de pouquíssima ou nenhuma repercussão no quadro geral e estrutural de desigualdades sociais. Do mesmo modo, condiciona-se a prática da cidadania ao ajuizamento de demandas perante o Judiciário - este tido como tutor de uma sociedade órfã e desprotegida de recursos financeiros, do acesso à cidadania ${ }^{19}$.

Os debates trazidos até aqui sobre a produção de efeitos das normas constitucionais demonstram os imensos paradoxos existentes na retomada dos processos democráticos dos países latino-americanos. Se, a uma, o simples menosprezo ao tamanho dos textos constitucionais, sem uma devida compreensão acerca das conjunturas transicionais, pode levar a um processo de depreciação das cartas constitucionais sem considerar todas as potencialidades que delas podem advir em sociedades marcadas por grandes deficits de garantias de direitos fundamentais, ou ainda, onde o próprio Estado constituiu-se como principal violador de direitos; por outro lado, as estratégias de efetivação constitucional que se consolidam, sobretudo no que diz respeito ao fenômeno da judicialização, encontraram um terreno fértil na América Latina das transições: poderes executivos com dificuldades de implementação dos direitos constitucionalmente garantidos, sociedades desacostumadas ao ritmo democrático das reivindicações

19 BELLO, Enzo. Cidadania e direitos sociais no Brasil: um enfoque político e social. In: SOUZA NETO, Cláudio Pereira de; SARMENTO, Daniel. Direitos Sociais: fundamentos, judicialização e direitos sociais em espécie. Rio de Janeiro: Lumen Juris, 2008. p. 177-227. p. 184. 
políticas e um sistema judicial que adquiriu protagonismo com os novos modelos de garantias de direitos contemplados nos textos constitucionais. Afinal, como destaca Veronese, "é necessário que haja um contexto institucional que permita ao ordenamento jurídico fixar as práticas sociais facilitadoras da judicialização. Esse processo não é uma questão de simples vontade por parte dos atores políticos". 20

A pauta da judicialização ocupa espaço central nos debates jurídicos e políticos das atuais sociedades latino-americanas, até porque não se pode pretender que, depois de longos anos enfrentando a repressão estatal e impossibilitadas de vivenciar processos políticos democráticos, as sociedades latino-americanas tenham que ficar submetidas politicamente à regência ou à tutela do Poder da República que menos possui vínculos de legitimação política com elas. Em última instância, a reflexão tem girado em torno da questão: a substituição do espaço público de organização política da sociedade pela via da judicialização contribui para o avanço de nossas democracias? Como produzir e qual o papel dos tensionamentos referidos diante desse quadro?

De todo modo, se está sendo possível chegar a esse ponto do debate jurídicopolítico de tentar enfrentar as grandes questões que se colocam a partir da relação entre direito e política é porque, em certa medida, os tensionamentos causados pela tendência da judicialização nas sociedades latino-americanas contribuíram para que isso ocorresse. Tão importante quanto enfrentar os efeitos perversos da judicialização é poder debater em um ambiente socioinstitucional, que se pretende consolidar como democrático, os paradoxos que permeiam as relações entre política e direito.

Portanto, a existência de tensionamentos, ainda que em contextos paradoxais, pode impulsionar disputas e debates que possibilitem um aprofundamento dos processos democráticos e o fortalecimento normativo dos textos constitucionais. Nesse sentido, não há como negar que, muito mais que outrora, todas essas grandes polêmicas judicializantes, de um jeito ou de outro, contribuíram para o 20 VERONESE, Alexandre. A judicialização da política na América Latina: panorama do debate teórico contemporâneo. In: Escritos. Revista da Fundação Casa de Rui Barbosa, Rio de Janeiro, ano 3, n. 3, p. 249-281. jan. 2009. p. 276. 
aumento dos níveis de efetivação dos textos constitucionais e para a preocupação que se deve ter com o tema.

\section{A JUSTIÇA DE TRANSIÇÃO COMO TEMÁTICA CATALISADORA DE TENSÕES SOCIAIS LATINO-AMERICANAS}

O conceito de justiça de transição é relativamente recente e não se confunde com a existência, em si, de processos de transições políticas. Trata-se de uma perspectiva que se consolidou teoricamente a partir de um conjunto de medidas normativas ${ }^{21}$ inspiradas nas reivindicações das vítimas dos regimes de exceção indispensáveis à consecução de transições que restabeleçam mecanismos de integração social. Segundo Marcelo Dalmás Torelly, sua origem na modernidade estaria vinculada ao fim da Segunda Guerra Mundial e englobaria, em sua definição:

[...] uma série de iniciativas empreendidas por via dos planos internacional, regional ou interno, nos países em processo de liberalização ou democratização, englobando suas políticas públicas, suas reformas legislativas e o funcionamento de seu sistema de justiça, para garantir que a mudança política seja bem-sucedida e que, ao final dela, não exista apenas uma democracia eleitoral (caracterizada por eleições procedimentalmente equitativas), mas, sim, um Estado de Direito na acepção substancial do tema ${ }^{22}$.

Portanto, nem todas as transições políticas são marcadas pela adoção ou implementação imediata das medidas próprias da justiça transicional e a adoção dessas medidas vincula-se tanto às decisões políticas institucionais como ao grau de organização e mobilização da sociedade civil em torno do tema. É importante perceber como a consolidação de um campo próprio da justiça de transição passou a impor uma pauta mais substancial em termos de garantias de

21 Identificam como medidas normativas exatamente por abarcar um conteúdo indicativo de como agir do melhor modo sob uma perspectiva moral. Assim, as quatro medidas próprias da justiça transicional que também trazem consigo uma dimensão de proteção de direito seriam: o acesso à verdade sobre os fatos ocorridos durante o período de exceção, a busca por justiça no sentido da responsabilização civil, administrativa e criminal dos agentes do Estado que cometeram os crimes de lesa humanidade, a reparação às vítimas e a necessidade de reformas institucionais que garantam a retomada do processo democrático.

22 TORELLY, Marcelo D. Justiça de Transição e Estado Constitucional de Direito. Belo Horizonte: Fórum, 2012. p. 105. 
direitos aos processos transicionais, já que, como a própria definição de Torelly indica, as pretensões de uma transição pura e simples apontam muito mais para a implementação de procedimentos de uma democracia formal, ou como dito pelo autor, eleitoral e, a justiça de transição, compreendida como uma temática de articulação social em torno da questão dos direitos humanos, principalmente quanto às reivindicações das vítimas das violações aos direitos ${ }^{23}$, passou a exigir uma resposta política mais ampla aos processos transicionais, sobretudo, quanto à proteção de direitos.

Por um lado, o campo da justiça de transição, compreendido como um espaço de articulação social das demandas por justiça dos grupos ou movimentos organizados de vítimas ou de apoio a essas vítimas, a depender das estratégias utilizadas, pode sofrer uma ampliação de seu alcance para conseguir o apoio de outras parcelas da população que não estejam diretamente vinculadas às violações de direitos, mas que passam a se identificar com essas reivindicações tanto pelo sentimento de solidariedade com os aqueles que sofreram as violações aos seus direitos, como também pelo reconhecimento da importância pública de uma comunidade política estar resguardada por um autêntico Estado de Direito, garantidor de direitos fundamentais capaz de enfrentar as graves violações aos direitos humanos. $E$, nesse ponto de interligação, é que se pode destacar a

23 A justiça de transição tem se firmado cada vez mais como uma temática que trata como prioridade os direitos das vítimas à justiça, à reparação, à memória e à verdade. Isso é fruto de uma apropriação da temática por parte dos movimentos de defesa das vítimas que sofreram as violações dos regimes de exceção, o que faz com que tais movimentos sejam peça chave na consolidação da temática da justiça de transição na maior parte dos países em processos transicionais, sobretudo na América Latina. Na leitura de Carlos Nino em "Juízo ao mal absoluto" isso fica claro em vários trechos. Conferir: NINO, Carlos. Juicio al mal absoluto. Buenos Aires: Ariel, 2006. p. 111, 124, 127. Do mesmo modo como no caso colombiano, em que Uprimny y Saffon identificam tais grupos como os grandes responsáveis pela explosão de debates acerca da temática no país. UPRIMNY, Rodrigo; SAFFON, María Paula. Usos y abusos de la justicia transicional en Colombia. In: Anuario de Derechos Humanos, 2008. Disponível em: www.anuariocdh.uchile.cl Acesso em: 12/05/2013. p. 171-175. Essa identificação de centralidade dos movimentos sociais é feita por Louis Bickford no verbete sobre Justiça de Transição da Enciclopédia de Genocídios e Crimes contra a Humanidade, em especial na seguinte passagem: "First, the human rights movement has strongly influenced the development of the field, making it selfconsciously victim-centric. Transitional justice practitioners tend to pursue strategies that they believe are consistent with the rights and concerns of victims, survivors, and victims' families." BICKFORD, Louis. Transitional Justice. In: The Encyclopedia of Genocide and Crimes Against Humanity. v. 3. New York: MacMillan, 2004. p. 1045-1047. p. 1045. Torelly, a partir da definição de Bickford, também destaca em seu texto a importância dessa característica da justiça de transição. TORELLY, Marcelo D. Justiça de Transição e Estado Constitucional de Direito. p. 106. 
importância de textos constitucionais que reforcem a importância da garantia e da proteção de direitos fundamentais como documento político interno basilar às reivindicações da sociedade, que dialoga com o conjunto de documentos internacionais de proteção aos direitos humanos.

Por outro lado, essas reivindicações também geram tensões importantes aos avanços político-institucionais de um país que podem ser determinantes para a consolidação democrática das sociedades em transição. Carlos Nino, no livro "Juízo ao mal absoluto", reconhece as dificuldades políticas enfrentadas por Raul Alfonsin, presidente argentino responsável pela transição política desse país, em atender às pautas dos movimentos por direitos humanos. Contudo, o simples fato de existir uma determinada pressão social sobre a temática força o plano institucional a tomar decisões que talvez não atendam integralmente aos reclamos sociais, mas que podem representar um avanço no cenário de conquistas democráticas. Isso fica claro no texto de Nino quando trata da aprovação da Lei de Obediência Devida na Argentina, em 1987, que, na prática, já vinha se constituindo desde 1984 como um critério interpretativo das leis militares, que permitiu a abertura dos primeiros processos criminais contra oficiais militares. Naturalmente, os movimentos por direitos humanos não gostaram da ideia de uma Lei que só responsabilizasse o alto escalão das forças armadas argentinas sob o fundamento de que haviam dado as ordens, o que lhes pareceu uma espécie de "anistia encoberta". Contudo, em um cenário mais global, a iniciativa política de responsabilizar justamente o alto escalão das forças armadas foi considerada por muitos como um ato de coragem política decisivo no processo de responsabilização dos torturadores, o que colocou a Argentina à frente no enfrentamento dos crimes ocorridos durante as ditaduras no contexto latinoamericano ${ }^{24}$. Em 2005, a Lei da Obediência Devida, ao lado da Lei do Ponto Final, foram consideradas inconstitucionais pela Corte Argentina, o que possibilitou a responsabilização de outros escalões das forças armadas ${ }^{25}$.

Oque importa afirmar nesse ponto é que a busca poruma transiçãojusta é geradora de disputas valorativas que desembocam em tensionamentos políticos e institucionais 
importantes. O que se destaca nesse texto é justamente a potencialidade para, a partir dessas tensões, consolidarem-se os processos democráticos, principalmente, quanto à afirmação de um Estado de Direito que privilegie a articulação de espaços políticos e sociais para a legitimação da força normativa das constituições.

Contudo,éprecisochamaraatenção para ofato deque, talcomoostensionamentos ocasionados pela judicialização, a justiça de transição, compreendida como uma estratégia de disputas valorativas geradoras de tensões sociais, não está livre de paradoxos. O caso colombiano é um exemplo disso ${ }^{26}$. A temática da justiça de transição passa a estar cada vez mais presente na sociedade colombiana, apesar da permanência de conflitos armados entre diversos grupos que, mesmo mediante constantes rodadas de negociações para a paz, dão sinais claros de resistência a uma transição para a paz. Mesmo assim, de acordo com Uprimny e Saffon:

[...] la mayoría de los actores involucrados en la discusión política sobre cómo enfrentar las atrocidades cometidas por los paramilitares promueven explícitamente el uso del lenguaje y los mecanismos de la justicia transicional, o por lo menos implícitamente usan la lógica y las categorías de la justicia transicional para analizar la situación colombiana ${ }^{27}$.

O uso das categorias da justiça de transição por parte dos grupos comprometidos com a resolução das situações de violações aos direitos humanos permitiu uma generalização desses critérios e a sua instrumentalização por outros atores envolvidos no conflito, como o próprio governo colombiano e até mesmo os grupos paramilitares, o que colocou a temática em franca disputa valorativa em um cenário altamente paradoxal. O contexto que compõe a aprovação da chamada Lei de Justiça e Paz, na Colômbia, reflete muito bem essa situação. Sob um forte discurso de buscar um equilíbrio entre a paz e as exigências de justiça feitas pelos grupos sociais ligados às vítimas das violações de direitos, o governo, utilizando

26 O conflito armado colombiano é extremamente complexo não só por sua longa duração, mas, sobretudo, pelos atores envolvidos: Estado, vários grupos guerrilheiros e grupos paramilitares de direita que visam combater os grupos guerrilheiros fora dos limites do estado de Direito e que mantêm relações estreitas com a elite econômica e também com agentes do Estado. UPRIMNY, Rodrigo; SAFFON, María Paula. Usos y abusos de la justicia transicional en Colombia. p. 167.

27 UPRIMNY, Rodrigo; SAFFON, María Paula. Usos y abusos de la justicia transicional en Colombia. p. 171. 
discursivamente os elementos da justiça transicional, conseguiu a aprovação no Congresso da Lei 975/05, a Lei de Justiça e Paz, que impõe penalidades brandas aos crimes de violações aos direitos, exige alguns deveres básicos quanto à busca pela verdade e prevê um sistema de reparações às vítimas ${ }^{28}$. Naturalmente rechaçada pelos grupos de defesa dos direitos humanos por ensejar uma "impunidade disfarçada", Uprimny e Saffon não têm dúvidas em afirmar que:

El uso manipulador de la justicia transicional es hecho esencialmente por el gobierno y los líderes paramilitares, pero también es ampliamente apoyado por una mayoría de la sociedad civil. Este uso consiste en utilizar una retórica generosa de la verdad, la justicia y la reparación, con el fin de ocultar y legitimar procesos parciales de impunidad ${ }^{29}$.

A pesar de reconhecer que existe um uso democrático da temática da justiça de transição que produziu efeitos políticos importantes para o contexto colombiano ${ }^{30}$, a análise dos autores demonstra muito bem que as disputas valorativas acerca da justiça transicional compõem contextos paradoxais e que, nem sempre, os resultados dos tensionamentos podem significar um avanço em termos de garantias de direitos. O caso a ser tratado a seguir, o brasileiro, tem vivido um momento muito peculiar de retomada do debate público sobre a necessidade de implementar como fator decisivo na consolidação de uma democracia substancial no país as medidas de justiça de transição. Esse processo é fruto de uma série de tensionamentos sociais e institucionais que tem significado avanços, sobretudo, no campo do aumento da força normativa do texto constitucional.

\section{TENSIONAMENTOS NA DEMOCRACIA BRASILEIRA PELA BUSCA DE CRITÉRIOS DE JUSTIÇA: AINDA É TEMPO DE TRANSIÇÃO}

A transição política brasileira tem tido um tempo diferenciado das demais experiências latino-americanas, em especial, em relação aos países do cone sul

28 UPRIMNY, Rodrigo; SAFFON, María Paula. Usos y abusos de la justicia transicional en Colombia. p. 172.

29 UPRIMNY, Rodrigo; SAFFON, María Paula. Usos y abusos de la justicia transicional en Colombia. p. 177.

30 UPRIMNY, Rodrigo; SAFFON, María Paula. Usos y abusos de la justicia transicional en Colombia. p. 190. 
que sofreram golpes de Estado e passaram por períodos de exceção semelhantes, sobretudo, no que diz respeito ao enfrentamento das questões que envolvem a implementação das medidas da justiça de transição. Isso se deve ao modo como a transição foi gestada pelos próprios militares, ainda à frente do governo, administrando a chamada abertura lenta e gradual. A aposta na concertação política de que um grande pacto iniciado com a Lei de Anistia de 1979 seria capaz de gerar um processo de esquecimento, em que a nação deveria olhar para frente e esquecer o passado, foi determinante para um arrefecimento institucional da busca por uma transição pautada nos critérios da justiça de transição. Como já foi demonstrado, o próprio chamamento de uma assembleia constituinte não exclusiva pode ser visto como um dos sinais de que a grande prosperidade da nação se encontrava no futuro e não no passado e isso significava que o "pacto" da transição incluía a intocabilidade das forças armadas ${ }^{31}$. Contudo, o texto constitucional não ignorou as forças políticas em disputa à época e contemplou medidas de reparação às pessoas atingidas por atos de exceção durante o período ditatorial (art. $8^{\circ}$ do ADCT), o que gerou o que hoje é a política pública mais forte do Estado brasileiro no campo da justiça de transição: o sistema reparatório ${ }^{32}$.

E é por isso que esse contexto precisa ser compreendido dentro do cenário de testilhas ideológicas que pautaram e ainda pautam a transição brasileira. Mesmo que, como citado anteriormente, houvesse uma estratégia de reabertura política a partir de uma Constituinte identificada, a priori, como inautêntica por ocorrer nas entranhas do próprio poder constituído do Congresso Nacional, também havia uma disputa política pelo processo de redemocratização que foi capaz de gerar tensionamentos sociais importantes, que refletiram avanços institucionais como o já citado direito constitucional à reparação aos que foram perseguidos políticos no tempo do regime de exceção.

De todo modo, é importante destacar que, ao longo de todos esses anos do processo de consolidação da democracia brasileira, os grupos de familiares

31 FAORO, Raymundo. Uma constituinte tutelada. In: DIAS, Maurício. A democracia traída. São Paulo: Globo, 2008. p. 67-94. p. 76.

32 Para uma leitura completa sobre o sistema reparatório brasileiro conferir: ABRÃO, Paulo; TORELLY, Marcelo D. Justiça de Transição no Brasil: a dimensão da reparação. In: Repressão e memória política no contexto ibero brasileiro: estudos sobre Brasil, Guatemala, Moçambique, Peru e Portugal, Brasília, DF: Ministério da Justiça. Comissão de Anistia, 2010. p.26-59. 
de mortos e desaparecidos políticos, assim como as próprias organizações de perseguidos políticos e também as entidades de defesa dos direitos humanos não deixaram de atuar (ainda que tenham se desarticulado ao longo dos anos) e pressionar as gestões governamentais no sentido de ampliar os avanços transicionais muito concentrados inicialmente nas questões reparatórias ${ }^{33}$, tampouco deixaram de lado a estratégia de tentar avançar juridicamente no âmbito da responsabilização, um desafio verdadeiramente pesado para a realidade brasileira se considerarmos todas as questões que envolvem o poder judiciário brasileiro no contexto ditatorial e da transição ${ }^{34}$. Se, por um lado, nosso sistema reparatório avançou muito, sobretudo, depois que passou a ser compreendido como um pilar da justiça de transição ${ }^{35}$, por outro, o país custa a

33 Muitos desses avanços são fruto de uma atuação institucional da comissão de Anistia a partir de 2007 que, ao reconhecer o importante papel da sociedade civil na construção da anistia no Brasil, passou a construir uma nova interpretação da Lei 10559/02: "Na avaliação empreendida pela Comissão de Anistia para reorganizar suas ações estratégicas para o período 2007-2010, foram considerados, portanto, os seguintes elementos: (i) a sociedade civil brasileira mais ampla desarticulou-se do tema da anistia, que passou a ser desenvolvido por setores isolados uns dos outros, com grande sobreposição de esforços e desperdício de energias, devendo o eixo prioritário de ação ser a promoção de atividades de rearticulação de uma causa esparsa, mas nunca esquecida; (ii) entre os poderes de Estado, o Executivo é, desde sempre, o principal artífice das medidas transicionais no Brasil, sendo ou seu executor direto, ou o promotor do debate público que pressiona aos demais poderes14, (iii) o processo de justiça transicional brasileiro não se resume às ações das duas comissões de reparação, e tal diagnóstico é nocivo, pois somado ao ataque reacionário contra o processo de reparação, obstaculiza o avanço da consolidação democrática brasileira". ABRÃO, Paulo; TORELLY, Marcelo D. Justiça de Transição no Brasil: a dimensão da reparação. p. 35.

34 Anthony Pereira, em um importante estudo comparado entre Brasil, Chile e Argentina, investigou o grau de envolvimento de cada poder judiciário dentro desses países e concluiu que o mais participante foi o brasileiro e que a ausência de reformas significativas contribui para a manutenção do que chama de "entulho autoritário". De acordo com o autor "O judiciário brasileiro, da mesma forma que os militares, continuou, mesmo depois da volta à democracia, como um grupo corporativo altamente isolado e privilegiado. Os salários do Judiciário brasileiro estão entre os mais altos do mundo, enquanto a eficiência dos tribunais, em termos do número de casos julgados, é relativamente baixa". PEREIRA, Anthony. Ditadura e Repressão: o autoritarismo e o Estado de Direito no Brasil, no Chile e na Argentina. São Paulo: Paz e Terra, 2010. p. 243. Conferir também BAGGIO, Roberta Camineiro; MIRANDA, Lara Caroline. Poder judiciário e Estado de exceção no Brasil: as marcas ideológicas de uma cultura jurídicas autoritária. In: Revista do Instituto de Hermenêutica Jurídica, n. 8, jan. 2010, p. 149-169.

35 Essa compreensão gerou a chamada "virada hermenêutica" na interpretação do sistema reparatório instituído pela Lei 10.559/02, que pode ser compreendida na seguinte explicação: "É essa correta percepção do que é a anistia brasileira - coerente com a luta histórica dos perseguidos políticos que a sustentaram - que levou a Comissão de Anistia a promover uma "virada hermenêutica" nas leituras usualmente dadas à lei n. 10.559/2002: não se trata de simples reparação econômica, mas gesto de reconhecimento das perseguições aos atingidos pelos atos de exceção. Tanto é assim que, a partir de 2007, a Comissão passou a formalmente "pedir desculpas oficiais" pelos erros cometidos pelo Estado consubstanciado no ato declaratório de anistia política. Corrigiu-se, dentro das balizas legais existentes, o desvirtuamento interpretativo que dava ao texto legal uma leitura economicista, uma vez que a anistia não pode - para fazer sentido como 
avançar na apuração das circunstâncias de violação aos direitos humanos e não avançou quase nada no debate acerca da responsabilização dos agentes públicos perpetradores dos crimes contra a humanidade.

Ainda assim, é graças a esses grupos mobilizados socialmente e à assunção da responsabilidade, por algumas instâncias institucionais, de não transformar a anistia brasileira em esquecimento, que é possível afirmar que hoje o poder judiciário brasileiro, compreendido como o poder que oferece maior resistência às questões da justiça de transição, tem sido instado a debater e a enfrentar o assunto. O grande protagonista no acolhimento das demandas judiciais de responsabilização das vítimas tem sido o Ministério Público Federal, que até o presente momento ingressou com seis Ações Civis Públicas (ACP), uma denúnciacrime e uma requisição de abertura de Inquérito Policial ${ }^{36}$. Das seis ACP's, duas estão em andamento, uma está suspensa, três foram extintas pelo juízo a quo e aguardam o resultado, ou de recurso de apelação, ou de embargos declaratórios. A denúncia-crime foi rejeitada e o pedido de abertura de Inquérito Policial foi distribuído para a $1^{a}$ Vara Federal de Uruguaiana-RS e ainda não foi apreciado.

Em que pesem as resistências apresentadas pelo poder judiciário, sobretudo, depois do julgamento da ADPF 153 que reconheceu a aplicabilidade da Lei de Anistia aos crimes cometidos pelos agentes do Estado durante o período do regime de exceção, se não fosse pelo acolhimento do Ministério Público Federal das denúncias das vítimas da sociedade civil, até hoje o debate jurídico acerca da responsabilização dos torturadores estaria no limbo do esquecimento.

Nesse sentido, a condenação do Brasil pela Corte Interamericana de Direitos Humanos (CIDH) no caso Julia Gomes Lund e outros vs. Brasil, em novembro de 2011, em ação levada ao Sistema Interamericano de Proteção dos Direitos Humanos pelos familiares dos desaparecidos políticos no conflito conhecido como Guerrilha do Araguaia, tem também cumprido um papel importante de tensionamento no campo institucional.

ato de um Estado fundado nos valores em que se funda o Estado brasileiro - ser vista como a imposição da amnésia ou como ato de esquecimento, ou de suposto e ilógico perdão do Estado a quem ele mesmo perseguiu e estigmatizou como subversivo ou criminoso." ABRÃO, Paulo; TORELLY, Marcelo D. Justiça de Transição no Brasil: a dimensão da reparação. p. 46.

36 Dados disponíveis em: http://www.prr3.mpf.mp.br/component/content/148?task=view. Acesso em: 25/08/2013. 
De todos os casos em que o Brasil foi condenado pela $\mathrm{CIDH}^{37}$, sem sombra de dúvidas, essa última condenação foi a que gerou o maior debate público sobre as responsabilidades estatais, ampliando o campo de tensionamentos para grupos da sociedade civil que passaram a também organizar-se em torno do tema, como os levantes populares da juventude ${ }^{38}$. Em resposta ao cumprimento da sentença, o poder executivo aprovou no Congresso Nacional a Lei 12.528/11, que instituiu a Comissão Nacional da Verdade para a apuração dos fatos ocorridos durante o regime de exceção e a Lei 12.527/11, conhecida como Lei de Acesso à Informação. Pode-se afirmar, portanto, que os efeitos das tensões geradas junto à CIDH resultaram em consequências positivas para o avanço da democracia brasileira, sobretudo, quanto à importância da garantia e quanto à proteção dos direitos das vítimas das violações aos direitos humanos cometidas pelo próprio Estado.

O poder judiciário, contudo, representado pela manifestação de alguns Ministros do Supremo Tribunal Federal (STF), como Marco Aurélio de Mello, resistiu aos termos da condenação da CIDH de que a Lei de Anistia 6683/79 não poderia ser aplicada por ser uma lei de autoanistia produzida ainda no regime ditatorial. O Ministro afirmou que "Essa é uma decisão que pode surtir efeito no campo moral, mas não implica a revogação da Lei da Anistia e a cassação da decisão do Supremo" ${ }^{39}$.

No âmbito do STF, o que se percebe é uma resistência grande em romper com a leitura de anistia como esquecimento e isso pode ser percebido, sobretudo, na decisão tomada alguns meses antes da condenação do Brasil na CIDH na

37 O Brasil foi condenado anteriormente nos seguintes casos: Damião Ximenes em 2006, Arlei Escher em 2009 e Sétimo Garibaldi em 2009.

38 Abrão e Torelly identificam essa nova etapa como a terceira da fase da luta pela anistia no Brasil, para os autores "atualmente, emergem no Brasil, novos movimentos sociais com o lema da busca de verdade e justiça, análogos aos movimentos que antes surgiram na Argentina e no Chile. Questionam a validade da lei de anistia. Exigem o cumprimento da sentença da Corte Interamericana de Direitos humanos para que sejam superados os obstáculos jurídicos para a responsabilização judicial dos agentes perpetradores de crimes contra a humanidade. Se, na primeira fase, os movimentos sociais demandavam liberdade, e, na segunda, reparação e memória, estes novos movimentos sociais avançam ainda amis a agenda da transição, inaugurando a terceira fase da luta pela anistia, ao demandarem verdade e justiça". ABRÃO, Paulo; TORELLY, Marcelo. Mutações do conceito de anistia na justiça de transição brasileira: a terceira fase da luta pela anistia. Revista Anistia Política e Justiça de Transição, Brasília, n. 07, p. 10-47. jan./jun. 2012. p. 42-3.

39 Disponível em: http://www.estadao.com.br/noticias/geral,a-condenacao-do-brasil, 655168,0.htm Acesso em: 25/08/2013. 
ADPF 153. Contudo, isso não determina que o Brasil não conseguirá avançar nas questões de responsabilização dos agentes do Estado que cometeram crimes de lesa humanidade. É preciso levar em conta que, além de todas as pressões sociais que se aprofundam a cada inciativa da sociedade civil e de algumas instâncias institucionais no campo da busca por uma justiça de transição, o Brasil está inserido em um contexto latino-americano, sobretudo, em relação aos países do cone sul, que favorece um debate jurídico sobre a importância e a necessidade de aplicação das normas de direito internacional dos direitos humanos. Nesse sentido, os debates travados pelos ministros do STF no âmbito de três extradições de agentes do Estado perpetradores de crimes contra a humanidade durante o regime ditatorial, requisitadas pela República Argentina, são muito elucidativos.

A primeira é a extradição 974, de Manuel Cordero, apreciada em 2009, portanto, antes do julgamento da ADPF 153, que, como já foi dito, acabou por reconhecer a legitimidade na atual ordem constitucional da Lei de Anistia de 1979, cuja interpretação tem levado à impunidade dos agentes torturadores durante o regime ditatorial brasileiro. A decisão, como se vê, é anterior à condenação do Brasil na CIDH no caso Gomes Lund. A segunda extradição é a 1150, de Norberto Raul Tozzo, e a terceira é a 1278, de Claudio Vallejos, ambas as últimas apreciadas posteriormente ao julgamento da ADPF 153 e à condenação do Brasil na CIDH.

O ponto de partida dessa análise é a identificação de uma resistência histórica por parte do STF em aplicar, no âmbito interno, tratados e convenções que versem sobre direitos humanos, cuja causa pode ser atribuída a razões semelhantes às que levam o Tribunal a manter em suas decisões uma concepção de anistia como esquecimento: o protagonismo judiciário durante o regime militar e sua consequente omissão na proteção de direitos humanos ${ }^{40}$.

Por mais que nossa Constituição tenha consagrado, desde sempre, em seu art. $5^{\circ}, \S 2^{\circ}$, a cláusula da materialidade aberta que permite a equiparação hierárquica

40 De acordo com Anthony Pereira "Todos os juízes participantes do processo costumavam acobertar as torturas sistematicamente praticadas contra os presos, e é provável que fossem exonerados se não o fizessem. Embora, em alguns raros casos ocorridos em fins da década de 1970, tenha acontecido de juízes absolverem os réus com base em alegações de tortura, isso nunca ocorreu no período de 1968 e 1974, o auge da linha-dura, quando juiz algum pediu investigações sobre os relatos de tortura". PEREIRA, Anthony. Ditadura e Repressão: o autoritarismo e o Estado de Direito no Brasil, no Chile e na Argentina. p. 127. 
desses tratados e convenções às normas constitucionais ${ }^{41}$, o STF sempre ignorou essa perspectiva e, apenas muito recentemente, depois da alteração constitucional feita pela Emenda 45/04, que acrescentou o $\S 3^{\circ}$ ao art. $5^{\circ}$, determinando um procedimento formal para tal equiparação, o STF reconheceu que essas normas internacionais poderiam ser consideradas como normas constitucionais, estabelecendo, contudo, uma categoria de norma supraconstitucional para tratados e convenções não submetidos ao procedimento formal ${ }^{42}$. Essa resistência histórica à aplicação de normas do direito internacional dos direitos humanos, mesmo após a alteração da Emenda 45/04, se reflete muito claramente como uma tendência ao afastamento da aplicabilidade dessas normas, o que ocorre na decisão das três extradições.

A Extradição 974 trata de um major do exército uruguaio que, como partícipe da chamada Operação Condor, é acusado, na Argentina, pelo desaparecimento de dez pessoas, em 1976, e a subtração de um menor do poder dos pais, que acabou sendo entregue para adoção, tendo sido essa efetivada pelo próprio delegado que recebeu a criança ${ }^{43}$. O relator da extradição, Ministro Marco Aurélio

41 De acordo com Flávia Piovesan: "Ao fim da extensa Declaração de Direitos enunciada pelo art. 50, a Carta de 1988 estabelece que os direitos e garantias expressos na Constituição "não excluem outros decorrentes do regime e dos princípios por ela adotados, ou dos tratados internacionais em que a República Federativa do Brasil seja parte". À luz desse dispositivo constitucional, os direitos fundamentais podem ser organizados em três distintos grupos: a) o dos direitos expressos na Constituição; b) o dos direitos implícitos, decorrentes do regime e dos princípios adotados pela Carta constitucional; e c) o dos direitos expressos nos tratados internacionais subscritos pelo Brasil. A Constituição de 1988 inova, assim, ao incluir, dentre os direitos constitucionalmente protegidos, os direitos enunciados nos tratados internacionais de que o Brasil seja signatário. Ao efetuar tal incorporação, a Carta está a atribuir aos direitos internacionais uma hierarquia especial e diferenciada, qual seja, a de norma constitucional". PIOVESAN, Flávia. Tratados Internacionais de Proteção dos Direitos Humanos: jurisprudência do STF. Revista Internacional de Direito e Cidadania, São Paulo, n. 1, v.1, p. 43-57. jun. 2008. p.48.

42 A interpretação de Piovesan à chegada da nova emenda é de que nada muda a consideração da hierarquia material dos tratados e convenções sobre direitos humanos: "Reitere-se que, por força do art. 50, $\S 20$, todos os tratados de direitos humanos, independentemente do quorum de sua aprovação, são materialmente constitucionais, compondo o bloco de constitucionalidade. O quorum qualificado está tão-somente a reforçar tal natureza, ao adicionar um lastro formalmente constitucional aos tratados ratificados, propiciando a "constitucionalização formal" dos tratados de direitos humanos no âmbito jurídico interno. Como já defendido por este trabalho, na hermenêutica emancipatória dos direitos há que imperar uma lógica material e não formal, orientada por valores, a celebrar o valor fundante da prevalência da dignidade humana. À hierarquia de valores deve corresponder uma hierarquia de normas22, e não o oposto. Vale dizer, a preponderância material de um bem jurídico, como é o caso de um direito fundamental, deve condicionar a forma no plano jurídiconormativo, e não ser condicionado por ela". PIOVESAN, Flávia. Tratados Internacionais de Proteção dos Direitos Humanos: jurisprudência do STF. p. 54.

43 A extradição de Manuel Cordero também foi requisitada pelo Uruguai. O STF entendeu, 
de Mello, apesar de citar a Convenção Interamericana sobre o Desaparecimento Forçado de Pessoas, que trata como imprescritível o crime cujo nome lhe intitula, afasta de plano sua aplicação sob a alegação de que tal convenção não está ratificada no plano interno. ${ }^{44}$

Em um segundo momento, o relator desqualifica o crime de sequestro como um tipo penal equivalente ao de desaparecimento forçado, uma vez que, tendo passado mais de trinta e dois anos do crime sem qualquer tipo de identificação sobre o paradeiro do desaparecido, presumir-se-ia que já está morto. Sustenta como base legal específica de tal presunção a Lei 9140/95, que reconhece como mortas as pessoas desaparecidas em virtude de participação ou acusação de participação em atividades políticas no período de 02 de setembro de 1961 a 05 de outubro de $1988{ }^{45}$. Da mesma forma, na Argentina, o art. 22 da Lei 14394/54 adota a presunção ao dispor que "A ausência de uma pessoa no lugar de seu domicílio ou residência na República, haja ou não deixado patrimônio, sem que dela se tenha notícia, findo o prazo de três anos, causa a presunção de seu falecimento. Esse prazo será contado desde a data da última notícia que se teve da existência do ausente" 46 . Desse modo, o tipo legal amoldado à conduta do acusado é o de homicídio, que já estaria prescrito tanto no Brasil como na Argentina, sendo inviável, nesses termos, o deferimento da extradição. Como "reforço" ao voto, o relator chama a atenção para o fato de que, caso o extraditado tivesse que cumprir pena no Brasil, estaríamos diante de uma situação delicada quanto ao alcance da Lei de Anistia 6683/79 e as consequências drásticas de uma possível reabertura das possibilidades de persecução penal no Brasil. Em suas próprias palavras:

Em última análise, o Supremo está a enfrentar, neste caso, na via indireta, é certo, a problemática alusiva a tema que, há pouco, esteve em voga - o alcance da anistia. Se deferida esta extradição, assentar-se-á a viabilidade de persecução criminal, de responsabilidade administrativa e civil, no tocante a fatos cobertos pela anistia e, então, esvaziada na

contudo, que teria preferência o pedido de extradição feito pelo estado em que o crime foi cometido, no caso a Argentina BRASIL. Supremo Tribunal Federal. Deferimento de pedido de extradição. Extradição 974. Argentina e Manuel Cordero. Relator: Ministro Marco Aurélio de Mello. 06 ago. 2009. Disponível em: http://redir.stf.jus.br/paginadorpub/paginador.jsp? docTP=AC \&docID=606492 Acesso em: 01 nov. 2012. p. 06.

44 BRASIL. Supremo Tribunal Federal. Deferimento de pedido de extradição. Extradição 974. p. 08. 45 BRASIL. Supremo Tribunal Federal. Deferimento de pedido de extradição. Extradição 974. p. 10. 46 BRASIL. Supremo Tribunal Federal. Deferimento de pedido de extradição. Extradição 974. p. 11. 
essência será esta última, não mais implicando a suplantação de quadra desejada. Feridas das mais sérias, consideradas repercussões de toda ordem, poderão vir a ser abertas. Isto não interessa ao coletivo, isso não interessa à sociedade presentes valores maiores. Isso resultará em retrocessos dos mais nefastos. Anistia é o apagamento do passado em termos de glosa e responsabilidade de quem haja claudicado na arte de proceder. Anistia é definitiva virada de página, perdão em sentido maior, desapego a paixões que nem sempre contribuem para o almejado avanço cultural. Anistia é ato abrangente de amor, sempre calcado na busca do convívio pacífico dos cidadãos. Eis o que se faz em jogo neste julgamento. Deferida a extradição, abertas estarão, por coerência, as portas às mais diversas controvérsias quanto ao salutar instituto da anistia. Grassará o conflito sem limites ${ }^{47}$.

O Ministro Ricardo Lewandowski sustenta sua divergência em relação ao relator, argumentando que há dupla tipicidade do crime de sequestro no Brasil e na Argentina e que não há que se falar em homicídio porque, em tese, o sequestro pode subsistir. Reforçando com uma série de outros argumentos a divergência do Ministro Lewandowski, Cezar Peluso destaca como questão básica o fato de que o Estado que julga a extradição não pode desqualificar o crime duplamente tipificado pelo Estado requerente, fruto, inclusive de todo seu aparato procedimental para a apuração dos fatos que estão sendo imputados como de responsabilidade do acusado. Nas palavras do ministro:

A reclassificação jurídica dos fatos para a categoria normativa de homicídios inovaria a própria base empírica do pedido de extradição, porque implicaria transpor, mediante simples exercício de conjectura, os limites da operação mental de subsunção para mudar, em consequência pressuposta, a situação concreta que, como objeto dos processos, motivou o pleito ${ }^{48}$.

De ouro lado, como forma de demonstrar a incoerência da invocação do direito civil para a presunção das mortes, o Ministro reúne uma série de jurisprudências e posições doutrinárias para demonstrar o quão complexa é a questão e como não há que se fazer essa ponte entre direito civil e direito penal sem o devido cuidado. Em conclusão, o ministro afirma:

47 BRASIL. Supremo Tribunal Federal. Deferimento de pedido de extradição. Extradição 974. p. 11-2.

48 BRASIL. Supremo Tribunal Federal. Deferimento de pedido de extradição. Extradição 974. p. 33. 
Em relação à prescrição, o problema que aventei, que cuido ter examinado à luz dos artigos $6^{\circ}$ e $7^{\circ}$ do Código Civil, é que, para que seja admitida a presunção, seja tanto para efeitos civis, como para efeitos penais, a presunção de morte tem de ser objeto de uma sentença, que, entre outras coisas, deve fixar a data provável do falecimento, porque sem tal sentença permanece sempre a dúvida. E, neste caso, nós nos remetemos, já não para a hipótese de morte presumida, mas para o instituto da ausência, que tem tratamento normativo completamente diferente e no qual não se presume morte alguma ${ }^{49}$.

Para sustentar uma concepção de transição como esquecimento, o Ministro Marco Aurélio de Mello prefere adotar uma argumentação jurídica frágil, de desqualificação de um tipo penal a partir da utilização de conceitos de desaparecimento de pessoas definidos em leis civis, a enfrentar o debate da aplicação das normas de direito internacional dos direitos humanos, nesse caso, especificamente a Convenção Interamericana sobre o Desaparecimento Forçado de Pessoa, descartada de plano no voto do relator. A Lei argentina citada pelo Ministro define a presunção de morte diante de situação de desaparecimento de pessoa para fins civis de destinação da herança e a Lei brasileira invocada pelo relator está direcionada ao reconhecimento das mortes por perseguição política para fins específicos de indenização do Estado, como parte do sistema reparatório brasileiro, o que torna, na melhor das hipóteses, a construção jurídica elaborada falaciosa.

A divergência levantada pelo Ministro Lewandowski e reforçada juridicamente pelo Ministro Cezar Peluso recebeu os votos dos ministros Joaquim Barbosa, Carlos Ayres Britto, Carmen Lúcia e Eros Grau, sendo que esses dois últimos reajustaram seus votos após a manifestação da divergência. Apenas o ministro Menezes de Direito acompanhou o relator.

O aspecto não jurídico que se destaca ao longo da leitura da íntegra da votação é um cuidado extremo com o tema da anistia no Brasil, que indica em alguns momentos o temor de que qualquer deslize pudesse comprometer o debate posterior da ADPF 153, já que, no momento do julgamento dessa extradição, a ADPF 153 já havia sido proposta pela Ordem dos Advogados do Brasil (OAB) e a relatoria do Ministro Eros Grau já estava definida. Tanto a primeira manifestação da Ministra Carmen Lúcia

49 BRASIL. Supremo Tribunal Federal. Deferimento de pedido de extradição. Extradição 974. p. 45. 
quanto a do Ministro Eros Grau acompanharam o Ministro relator, mas sempre fazendo a ressalva de que não queriam se comprometer com a tese da anistia por ele levantada. O Ministro Eros Grau chega a pedir vista do processo com o indicativo de que a extradição talvez tivesse que ser apreciada junto com a ADPF 153, o que foi contestado pelo Ministro Cezar Peluso pelo receio de que a apreciação de situações diferentes acabasse submetendo-as ao mesmo tipo de pressão ${ }^{50}$.

Após o julgamento da Extradição 974, o STF reconheceu a legitimidade da Lei de Anistia de 1979, em abril de 2010, no julgamento da ADPF 153, mantendo a impossibilidade de persecução penal pelos crimes e violações aos direitos humanos, sem qualquer profundidade de análise do tema da aplicação dos tratados e convenções internacionais sobre direitos humanos. ${ }^{51} \mathrm{Em}$ novembro de 2010, o Brasil é condenado pela CIDH no caso Julia Gomes Lund e outros, conhecido popularmente como Caso Guerrilha do Araguaia, reconhecendo a mora do Estado brasileiro na busca dos corpos dos guerrilheiros e o direito das vítimas de acesso à verdade sobre os fatos. As outras duas extradições mencionadas foram julgadas pelo STF depois desses fatos.

A Extradição 1150 foi apreciada, em 2011, sob a relatoria da Ministra Carmen Lúcia e trata do caso de Norberto Raul Tozzo, um dos granes responsáveis pelo conhecido massacre de Margarita Belén. Segundo os fatos apurados pela República Argentina, Tozzo teria sido o protagonista em uma emboscada armada para matar detidos que estavam sob a custódia do exército argentino a caminho da província de Formosa. A chacina pretendia simular uma emboscada feita por subversivos que teriam supostamente atacado a coluna militar. Vinte e duas pessoas morreram, algumas estão desaparecidas até hoje. Os crimes cometidos por Tozzo, portanto, seriam os de homicídio e desaparecimento forçado.

Apesar do reconhecimento da prescritibilidade dos crimes de homicídio e da ausência de qualquer argumento normativo vinculado ao direito internacional

50 BRASIL. Supremo Tribunal Federal. Deferimento de pedido de extradição. Extradição 974. p. 53.

51 Para uma análise completa sobre o julgamento da ADPF 153 conferir MOREIRA FILHO, José Carlos. O Julgamento da ADPF 153 pelo Supremo Tribunal Federal e a Inacabada Transição Democrática Brasileira. In: PIOVESAN, Flávia; SOARES, Inês Virginia Prado (Coords.). Direito ao desenvolvimento. São Paulo: Fórum, 2010. 
dos direitos humanos, sobretudo quanto à imprescritibilidade dos crimes contra a humanidade, a relatora afirmou não haver ocorrido a prescrição dos crimes de desaparecimento forçado, reconhecendo sua equivalência interna ao crime de sequestro ${ }^{52}$, resultando na decisão de votar "[...] no sentido de deferir o pedido de extradição tão somente pelos crimes de desaparecimento forçado de pessoas, considerada a dupla tipicidade do crime de sequestro qualificado" ${ }^{\prime 53}$

Outro aspecto do voto é que a relatora afastou a tese da defesa do acusado de que os crimes cometidos por ele seriam crimes de natureza política, reafirmando a sua condição de crimes comuns. Essa questão é bastante relevante, porque um dos pontos centrais na decisão da ADPF 153 é a reafirmação da interpretação dada à Lei $6683 / 79$ de que os crimes cometidos por agentes do Estado seriam crimes conexos aos crimes políticos e que estariam, por isso, englobados na previsão de anistia da referida Lei. A Ministra Carmen Lúcia acompanhou o voto do relator, Ministro Eros Grau, no julgamento da ADPF 153, contudo, não aderiu completamente, naquele momento, à tese da conexão entre os crimes. A manutenção de tal interpretação, de acordo com a Ministra, seria uma espécie de dever histórico que cumpriria o objetivo de não ofender o princípio da irretroatividade das leis e, para tanto, a interpretação mais conveniente seria aquela que não considera a conexão em um sentido técnico restrito, mas como um conceito mais amplo. O trecho mais relevante de sua argumentação, à época, é o que segue:

De se notar que este Supremo Tribunal já se debruçou sobre o sentido da conexão referida no $\S 1^{\circ}$ do art. $1^{\circ}$ da Lei 6683 , por exemplo, ao julgar o recurso em habeas corpus 59.834, relator o Ministro Firmino Paz. Naquela ação, o Ministro Décio Miranda, acentuou em seu voto, que "a lei de anistia, Lei 6683/79 não adotara um conceito rigoroso a este propósito (conexão) tanto que depois de referir, no artigo $1^{\circ}$, crimes políticos ou conexos com estes, achou prudente no $\S 1^{\circ}$ do mesmo artigo definir a indicada conexão... não estamos diante do conceito rigoroso de conexão, mas de um conceito mais amplo, em que o legislador considerou existente esta figura processual, desde que se pudesse relacionar uma infração à outra (...) Nenhuma dúvida me acomete quanto à não conexão técnico-

52 BRASIL. Supremo Tribunal Federal. Deferimento de pedido de extradição. Extradição 1150. Argentina e Norberto Tozzo. Relatora: Ministra Carmen Lucia. 19 mai. 2011. Disponível em: http://redir.stf.jus.br/paginadorpub/paginador.jsp?docTP=AC\&docID=624223 Acesso em 01 nov 2012. p. 40.

53 BRASIL. Supremo Tribunal Federal. Deferimento de pedido de extradição. Extradição 1150. p. 44. 
formal dos crimes de tortura com qualquer crime outro, menos ainda de natureza política. Tortura é barbárie, é o desumanismo da ação de um ser mais animal que gente, é a negação da humanidade, mais que a dignidade, que quem a pratica talvez nem ao menos saiba o que tanto vem a ser. Não vejo como, para efeitos específica e exclusivamente jurídicopenais, nós, juízes, reinterpretarmos, trinta e um anos após e dotarmos de efeitos retroativos esta nova interpretação, da lei que permitiu o que foi verdadeiro armistício de 1979 para que a guerra estabelecida pelos então donos do poder com os cidadãos pudesse cessar. Não vejo como, judicialmente, possa ser, agora, aquela lei reinterpretada com negativa, ampla, geral e irrestrita de tudo o que ocorreu então e que permitiu que hoje fosse o que se está a construir ${ }^{54}$.

O Ministro Ricardo Lewandowski, na Extradição 1150, acompanhou o voto da relatora e o Ministro Marco Aurélio divergiu com base no seu voto na Extradição 974, afirmando que "[...] por mais que me sensibilize com o que ocorreu - na Argentina, em outros países da América Latina, inclusive no Brasil - , não posso simplesmente olvidar esses aspectos e partir para a conclusão de ter-se um pedido legítimo na espécie" 55 .

De outro lado, o Ministro Luiz Fux, que substituiu a vaga deixada pela aposentadoria do Ministro Eros Grau, demonstrou uma enorme comoção em estar tratando do caso do massacre de Margarita Belén. Inicia seu voto com a seguinte observação:

[...] esse é um momento importante para minha geração, porque esse massacre de Margarita Belén foi exatamente um evento político que marcou muito a minha juventude, assim como também a explosão da bomba do Riocentro e todos esses eventos que se encaixam bem na advertência de um poeta latino de que "quando não lembramos do que nos aconteceu, pode vir a acontecer tudo outra vez"56

A frase do poeta latino é repetida ainda mais uma vez e, depois de ler um trecho relativamente grande de uma mensagem de Gustavo Piérola destinada aos jovens mortos no massacre, o Ministro conclui:

54 BRASIL. Supremo Tribunal Federal. Deferimento de pedido de extradição. Extradição 1150. p. 97.

55 BRASIL. Supremo Tribunal Federal. Deferimento de pedido de extradição. Extradição 1150. p. 51.

56 BRASIL. Supremo Tribunal Federal. Deferimento de pedido de extradição. Extradição 1150. p. 46. 
Este processo que trata do massacre de Margarita Belén representa a humanidade, a sensibilidade e a seriedade com que o Brasil resgata a história do nosso país e dos países de alhures. Não é outra razão que a nossa Constituição garante a igualdade a brasileiros e a estrangeiros. ${ }^{57}$

A última extradição ocorrida no Brasil que envolve crimes contra a humanidade praticados durante regimes de exceção, a 1278, foi julgada no ano de 2012, sob a relatoria do Ministro Gilmar Mendes e não altera significativamente o cenário explorado até aqui. Afastando a aplicação interna por falta de ratificação da Convenção Interamericana sobre o Desaparecimento Forçado de Pessoas, o Ministro adota a solução das extradições anteriores, reconhecendo prescrição do crime de homicídio e a dupla tipicidade do crime de sequestro, determinando o deferimento da extradição de Claudio Vallejos, requerida pela República da Argentina, pelo cometimento, por parte do acusado, dos crimes de homicídio e desaparecimento forçado. ${ }^{58}$

Algumas questões importantes podem ser depreendidas após esse rápido panorama sobre o tratamento do tema da anistia no STF. A primeira observação é que, mesmo após a suposta mudança de posição do STF quanto à consideração de supralegalidade dos tratados e das convenções de direitos humanos que não passaram pelo novo procedimento constitucional estabelecido pela EC 45/04, a resistência ao debate da aplicação das normas de direito internacional dos direitos humanos continua. O que parece, diante das negativas de aplicação da Convenção Interamericana sobre o Desaparecimento Forçado de Pessoas, é que a ratificação interna é necessária, imprescindível, sem qualquer tipo de ressalva ao debate feito nas questões sobre o depositário infiel acerca do caráter de supralegalidade dessas normas no ordenamento jurídico nacional. A Ministra Carmen Lúcia parece ter ficado mais à vontade na relatoria da Extradição 1150 para usar a tipologia do crime de desaparecimento forçado adotada pela Argentina a partir da Convenção, fazendo a equivalência interna ao crime de sequestro. Todavia, não tocou na existência da referida Convenção.

57 BRASIL. Supremo Tribunal Federal. Deferimento de pedido de extradição. Extradição 1150. p. 48.

58 BRASIL. Supremo Tribunal Federal. Deferimento de pedido de extradição. Extradição 1278. Argentina e Claudio Vallejos. Relator: Ministro Gilmar Mendes. 18 set. 2012. Disponível em: http://redir.stf.jus.br/paginadorpub/paginador.jsp?docTP=TP\&docID=2875328 Acesso em: 01 nov. 2012. p. 06. 
Outro aspecto importante de ser observado é que, durante o julgamento da ADPF 153, muitos termos próprios da justiça de transição foram apropriados para a sustentação da tese da anistia como esquecimento ${ }^{59}$. Por um lado, se parece esquizofrênico invocar o direito à memória e à verdade como sustentação de uma estratégia de não enfrentamento do passado, por outro, isso força - em certa medida - os integrantes do STF a não ignorar o debate acerca da justiça de transição e dá abertura para que um Ministro como Luiz Fux, que não participou de toda a pressão anterior ao julgamento da ADPF 153, mas que está hoje à frente da relatoria dos embargos declaratórios impetrados pela OAB para que a o STF deslinde sua posição quanto à lei de Anistia após a condenação do Brasil na CIDH, se aproprie dos conceitos da justiça de transição para enaltecer o papel do Brasil no processo regional de reconstrução democrática a partir da invocação do texto constitucional, como ocorreu em sua manifestação no julgamento da Extradição 1150.

Por fim, é importante ressaltar que a tentativa de manutenção da coerência por parte da Ministra Carmen Lúcia quanto à consideração dos crimes cometidos durante os regimes de exceção serem crimes comuns e não políticos ou conexos reforça o quanto é difícil manter tecnicamente a decisão da ADPF 153 e, consequentemente, qual deve ser a estratégia enfrentada para que a disputa jurídica acerca da responsabilização dos torturadores permaneça presente no Brasil: a questão da retroatividade da lei penal. Outros países latino-americanos já vivenciaram tensionamentos parecidos e conseguiram consolidar perspectivas importantes de aplicação do Direito Internacional dos Direitos Humanos ${ }^{60}$. Por

59 Houve uma utilização muito frequente na ADPF 153 sobre a dimensão do direito à verdade. Construções próprias dos debates acerca da necessidade de não esquecer o passado para que não se repitam os fatos foram claramente invertidas com frases como a da Ministra Ellen Gracie: "Não é possível viver retroativamente a história, nem se deve desvirtuá-la para que assuma contornos que nos pareçam mais palatáveis. Uma nação tem sua dimensão definida pela coragem com que encara seu passado, para tirar as lições que Ihe permitam nunca mais repetir os erros cometidos" ou, ainda, da Ministra Carmen Lúcia: "É certo que todo povo tem direito de conhecer toda a verdade da sua história, todo o cidadão tem o direito de saber o que o Estado por ele formado faz, porque faz e para que faz. Todo o povo tem o direito de saber, mesmo dos seus piores momentos. Saber para lembrar, lembrar para não esquecer e não esquecer para não repetir erros que custaram vidas e que marcam os que foram sacrificados por pais torturados, irmãos desaparecidos, dentre outras atrocidades" BRASIL. Supremo Tribunal Federal. ADPF 153. Relator: Ministro Eros Grau. 29 abr. 2010. Disponível em: http://redir.stf.jus.br/paginadorpub/paginador. jsp?docTP=AC\&docID=612960. Acesso em: 01 nov. 2012. p. 153 e p. 80.

60 Na Argentina essa questão foi objeto de uma grande controvérsia jurídica. Na passagem seguinte, destacam-se algumas considerações de Carlos Nino sobre o tema: "El sistema 
mais que os avanços do debate da justiça de transição no âmbito do poder judiciário brasileiro pareçam pequenos, há alguns anos a própria existência desses debates era inimaginável.

O que se quer apontar com o debate proposto nesse texto é que os desafios do constitucionalismo latino-americano guardam raízes comuns nos períodos de autoritarismo que dominaram por décadas a realidade desses países. Esses desafios são enfrentados na medida em que as disputas valorativas das sociedades ensejem tensionamentos político-jurídicos nas instâncias institucionais. A tentativa de avançarmos para a consolidação de um Estado Constitucional de Direito que valoriza dissensos próprios de uma sociedade democrática exige o enfrentamento do desafio de estabelecermos relações de complementaridade entre política e direito ou, ainda, entre democracia e proteção dos direitos. Diferentemente das estratégias de judicialização que procuraram consagrar tensionamentos no campo jurídico estrito de efetivação de direitos, a temática da justiça de transição possui um potencial de criar tensões que obrigam um debate não só jurídico sobre a proteção dos direitos, mas, sobretudo, político, que aponta para uma reflexão normativa de cunho moral indispensável para as sociedades latino-americanas: em que tipo de sociedade queremos viver?

\section{REFERÊNCIAS}

ABRÃO, Paulo; TORELLY, Marcelo D. Justiça de Transição no Brasil: a dimensão da reparação. In: Repressão e memória política no contexto ibero brasileiro: estudos sobre Brasil, Guatemala, Moçambique, Peru e Portugal, Brasília, DF: Ministério da Justiça. Comissão de Anistia, 2010. p. 26-59.

de prescripciones no es relevante para la legalidad del acto. La prevención como forma de castigo no está de ninguna forma calificada por la delimitación de un tiempo durante el cual la demanda del Estado de castigar podría expirar. Aun si justificamos un sistema de prescripciones basados en que los individuos cambian con el tiempo, esta justificación no tiene nada que ver con las razones subyacentes por las que la ley busca prevenir este tipo de actos. La gente debe decidir si comete o no un acto de acuerdo con normas de ilegalidad y consecuentemente corre el riesgo de confiar en factores que son irrelevantes para esas normas. Si alguien comete un crimen porque espera que antes de ser detenido la prescripción expire, debe cargar con haber confiado en factores ajenos a la legalidad del acto, como la persona que espera que no será castigada porque todas las prisiones del país incendiarán. Por lo tanto no creo que el principio contra la legislación penal retroactiva sea un obstáculo para extender o abolir normas de prescripción para abusos masivos a los derechos humanos. La única cuestión que puede legítimamente surgir es si resuelta justo castigar a alguien por actos realizados en el pasado distante cuando la persona ha cambiado significativamente en el ínterin." NINO, Carlos. Juicio al mal absoluto, p. 255-6. 
Mutações do conceito de anistia na justiça de transição brasileira: a terceira fase da luta pela anistia. Revista Anistia Política e Justiça de Transição, Brasília, n. 07, p. 10-47. jan./jun. 2012.

BAGGIO, Roberta Camineiro. Justiça de transição como reconhecimento: limites e possibilidades do processo brasileiro. In: Repressão e memória política no contexto ibero brasileiro: estudos sobre Brasil, Guatemala, Moçambique, Peru e Portugal, Brasília, DF: Ministério da Justiça. Comissão de Anistia, 2010. p. 260-285.

BAGGIO, Roberta Camineiro; MIRANDA, Lara Caroline. Poder judiciário e estado de exceção no Brasil: as marcas ideológicas de uma cultura jurídicas autoritária. Revista do Instituto de Hermenêutica Jurídica, Belo Horizonte, n. 8, p. 149-169. jan. 2010.

BELLO, Enzo. Cidadania e direitos sociais no Brasil: um enfoque político e social. In: SOUZA NETO, Cláudio Pereira de; SARMENTO, Daniel. Direitos Sociais: fundamentos, judicialização e direitos sociais em espécie. Rio de Janeiro: Lumen Juris, 2008. p. 177-227.

BICKFORD, Louis. Transitional Justice. In: The Encyclopedia of Genocide and Crimes Against Humanity. v. 3. New York: MacMillan, 2004. p. 1045-1047.

BRASIL. Supremo Tribunal Federal. Deferimento de pedido de extradição. Extradição 974. Argentina e Manuel Cordero. Relator: Ministro Marco Aurélio de Mello. 06 ago. 2009. Disponível em: http:// redir.stf.jus.br/paginadorpub/ paginador.jsp?docTP=AC\&docID=606492 Acesso em: 01 nov. 2012.

BRASIL. Supremo Tribunal Federal. Deferimento de pedido de extradição. Extradição 1150. Argentina e Norberto Tozzo. Relatora: Ministra Carmen Lucia. 19 mai. 2011. Disponível em: http://redir.stf.jus. br/paginadorpub/ paginador. jsp?docTP=AC\&docID=624223 Acesso em 01 nov 2012.

BRASIL. Supremo Tribunal Federal. Deferimento de pedido de extradição. Extradição 1278. Argentina e Claudio Vallejos. Relator: Ministro Gilmar Mendes. 18 set. 2012. Disponível em: http://redir.stf.jus. br/paginadorpub/ paginador. jsp?docTP=TP\&docID=2875328 Acesso em 01 nov. 2012.

BRASIL. Supremo Tribunal Federal. ADPF 153. Relator: Ministro Eros Grau. 29 abr. 2010. Disponível em: http://redir.stf.jus.br/paginadorpub/paginador.jsp?docTP=AC\&docID=612960 Acesso em 01 nov. 2012. p. 153 e p. 80.

FAORO, Raymundo. Constituinte ou Congresso com Poderes Constituintes? In: Constituição e Constituinte. São Paulo: RT, 1987. p. 11-28.

. Uma constituinte tutelada. In: DIAS, Maurício. A democracia traída. São Paulo: Globo, 2008. p. 67-94. 
GARGARELA, Roberto; COURTIS, Christian. El nuevo constitucionalismo latinoamericano: promesas e interrogantes. CEPAL, Serie Políticas Sociales, Santiago de Chile, n. 153. nov. 2009.

Apuntes sobre el constitucionalismo latinoamericano del siglo XXI. Apuntes históricos. Revista del Instituto de Ciencias Jurídicas de Puebla, México, p. 30-48. 2010.

HESSE, Konrad. A força Normativa da Constituição. Porto Alegre: Sérgio Fabris, 1991.

LASSALE, Ferdinand. A Essência da Constituição. Rio de Janeiro: Lumen Juris, 2000.

LOEWENSTEIN, Karl. Teoría de la constitución. Barcelona: Ariel, 1979.

LOPES, Júlio Aurélio Vianna. A invasão do direito. Rio de Janeiro: FGV, 2005.

MOREIRA FILHO, José Carlos. O Julgamento da ADPF 153 pelo Supremo Tribunal Federal e a Inacabada Transição Democrática Brasileira. In: PIOVESAN, Flávia; SOARES, Inês Virginia Prado (Coords.). Direito ao desenvolvimento. São Paulo: Fórum, 2010.

NEVES, Marcelo. Transconstitucionalismo. São Paulo: Martins Fontes, 2009.

NINO, Carlos. Juicio al mal absoluto. Buenos Aires: Ariel, 2006.

PEREIRA, Anthony. Ditadura e Repressão: o autoritarismo e o Estado de Direito no Brasil, no Chile e na Argentina. São Paulo: Paz e Terra, 2010.

PIOVESAN, Flávia. Tratados Internacionais de Proteção dos Direitos Humanos: jurisprudência do STF. Revista Internacional de Direito e Cidadania, São Paulo, n. 1, v.1, p. 43-57. jun. 2008.

SARTORI, Giovanni. Engenharia Constitucional: como mudam as constituições. Brasília: UnB, 1999.

TORELLY, Marcelo D. Justiça de Transição e Estado Constitucional de Direito. Belo Horizonte: Fórum, 2012.

UPRIMNY, Rodrigo; SAFFON, María Paula. Usos y abusos de la justicia transicional en Colombia. In: Anuario de Derechos Humanos, 2008. Disponível em: www.anuariocdh.uchile.cl Acesso em: $12 / 05 / 2013$.

VERONESE, Alexandre. A judicialização da política na América Latina: panorama do debate teórico contemporâneo. In: Escritos. Revista da Fundação Casa de Rui Barbosa, Rio de Janeiro, ano 3, n. 3, p. 249-281. jan. 2009. 